\title{
Ben, A Stranger in The Dark Society of Mirrors
}

\author{
Neda Raefipour*
}

\begin{abstract}
The research discusses Kristevan concepts of "thetic break", "loving father", "society of spectacle" and "stranger" in the two novels of Doris Lessing; The Fifth Child (1988) and Ben in The World (2000). The study is actually an attempt to illustrate how all characters of the novels, especially Ben, become successful in completing their psychic cycle. The characters' failure or success in making their "thetic break" by the help of their imaginary fathers is the main concern of the researcher. Being compelled to live in a society which is replete with mirrors, the subjects are afflicted with the lack of stable identities. The lack entails the entrance of a stranger in society, so all the features of such a person among other residents of society is the work under analysis by the researcher. At first step, the researcher does her best in analyzing all characters, especially Ben, psychoanalytically. The second step taken by her is to find traces of Kristeva's society of spectacle in Ben's society. The important and pivotal fact that makes such a study a novel one is that unlike other studies that focus upon Kristeva's internal psychoanalytical notions, the study concentrates on the social factors influential in identity formation such as Kristevan power and society of spectacle.From the researcher's perspective, it is not only internal factors, but also external and social ones that make a subject different from other ones.
\end{abstract}

Keywords: thetic break, imaginary father, love, stranger and society of spectacle, subject in process

\footnotetext{
* Corresponding author: Neda Raefipour M.A. student of English Language and Literature at Islamic Azad University at Tehran Central Branch; e-mail: bamegely@yahoo.com
} 


\section{Introduction}

Doris Lessing was born on 22 October 1919 in Kermanshah of Iran , her fiction in the word of Margaret Rowe and in her book Dreaming fathers, Practical mothers and Lessing's Fiction(1995), is a kind of tension between paternal and maternal elements, in the researcher's notion in all novels of Lessing " the father is as a dreamer and the mother as a regulator"(8), in other words, the writer believes that there is a battle between "action and reflection" in both Lessing's life and her literary works. What is so considerable in Row's analysis of Lessing's fictions is her capability to show how skillfully the marvelous writer blends the paternal and maternal roles in her novels. Ultimately she concludes that all maternal concerns in Lessing's novels are ascendant as in some of her novels such as The Fifth Child, readers can explore the unconventional maternal atmospheres in the mother-child bond. The Fifth Child and its sequel Ben in The World are fictions which really open a new lease of life for the readers.

The Fifth Child was published in 1988 and after two years its sequel Ben in The World appeared. Lessing's The Fifth Child portrays the life of an intimate couple called David and Harriet, whose life is loaded with happiness. After a while the couple decides to have children, so Harriet gives birth to four healthy babies, but their fifth child becomes a drawback, a retarded boy. The event shatters the unity of Lovatt's family; in other words, the presence of Ben changes everything in his family; therefore, he leaves his home and in Ben in The World enters the outside world i.e. his society. Ben, as the protagonist of these two novels, makes lance with many excruciating pains and problems and at the end of the novel commits suicide.

\section{Argument}

From Kristeva's point of view, the society in which modern subjects live is different from other kinds of societies; she calls it the society of spectacle. The society is founded upon images and spectacles; as a consequence, the residents of the society are obsessed with some 
dictated, fixed and manipulated images which have been constructed by those in power. Immersion in the society takes the inner psychic lives of its individuals away; therefore, all subjects become like automatons doing what their society desires. There are many reasons for the unconscious, automatic obedience; one of those is that in the society the individuals are devoid of any real, subjective self; their inner identity has been replaced with a fixed and petrified image shaped by ideology. Therefore, the subject is not a real one but an actor who can obtain a variety of personalities; he is in fact nobody but just a spectacle without any stable identity. Accordingly, the society is a dead one, without any live subjects in it. The Fifth Child and Ben in The World are the exact portrayal of individuals who live in Kristeva's society of spectacle. It is better to enumerate and explain the prominent elements of the society in Ben's community, either in The Fifth Child or in Ben in The World. The first case is the existence of some fixed criterions for living; In Ben's society, financial prosperity is one of the most important factors for a successful subject; in other words, in the society happiness and social state revolve around the factor. Johnston and Richard do their best to gain more and more money, even by illegal activities such as smuggling, David works from day to night to remain rich. The subjects in their community have become the tools of economic satisfaction of those in powers, consciously or unconsciously. In Ben's community, the desires are not their own but those of ideology which are artificially produced; in other words, the culture of the society has obliged its residents to have a value and its opposite, a self and other, the identical and alien. Economic prosperity and a healthy family without any retarded child in it are some examples of values in Ben's society.

As mentioned before, self-alienation of subjects is another side effect of the society; nearly all characters of the novels are self-alienated and as a consequence completely stranger to their real needs. The alienation is observable from Harriet who just for giving birth to a drawback always calls herself criminal, to female characters who for the fear of being rejected by their males, dispense with their inside stranger (Ben). The females such as Harriet and Rita finally leave Ben behind; because, they don't desire to become detached from their symbolic life. In researcher's 
notion, the self-alienation of all subjects of the novels has a main reason and it is the dissolution of their families.

In Ben's society, there are individuals who are deprived of any stable and proper family; in other words, the subjects lack a proper family which from Kristeva's perspective is a vital element for the construction of a perfect identity. The effect of the canon and its vital role in people's psyche can be illustrated in the examples of David and Harriet who are utterly different from each other psychoanalytically. The main reason for the difference is their family background: "Harriet's parents had taken it for granted that family life was the basis for a happy one while David's background was a quite different matter, his parent had divorced when he was 7" (13).As readers can obviously observe, David unlike Harriet doesn't have a calm and relaxed character, he is a strict father and husband, without any real sense of imaginary, as Kristeva explains "conjunction to unsatisfactory family relations lead to an impoverishment of the capacity to fantasize, drives are not represented in the psyche, they find expression in acts, acts of violence" (Oliver 46); therefore, the main reason for David's violent actions is concealed in his family. The savageness also exists in teenager's gang, john's group and Ben; what is common between all the characters is their lack of a suitable family. This lack manifests itself in self-alienated subjects having aggressive behaviors.

Kristeva believes that the society which is replete with self-alienated, violent and outrageous subjects use some of its tools to maintain its dominance and control over individuals. Some of these elements are mass media and visual representations, which act in support of the society's ideological purposes; "technology such as media provides us cliché images -the ready-made ones that act as softener-cleaning anxiety and with the bombardment of images the effect is to saturate the purpose of psyche that the image stops any questioning" (Letche 152). The individuals mesmerized by media and technology, unconsciously stop any form of resistance and questioning, like Ben's people.

Ben's society is loaded with ideological tools which function so perfectly in support of ideological ends; one of the tools is TV, which plays a pivotal role in every part of individuals' lives. There are many 
scenes in which TV teaches the subjects how to act and even how to speak, like Ben and his siblings who imitate exactly what happens in serials.

In Kristeva's notion, the society of spectacle has two features: the first one is the status of power and the second one is the status of the subject. She believes that in society of spectacle, residents experience a new version of power; in the sense that it is so much in favor of business and mafia activities and at the same time is completely invisible. Individuals in the case don't feel any justice exerted by the power; instead of justice and reality they observe media theatricalization. Thus, the individuals become a kind of property without any fixed identity. Ben's society has the exact features mentioned above; power in the society has entrapped individuals in different ways. David is mad for business, to the extent that he has dedicated all his life to it, Johnston and Richard are other characters whose deeds are in support of the invisible power governing them. To put it in another words, all characters of the novels from Johnston and David up to Richard and Alex act as their invisible power's tools; some have merged with its economic tricks, others have taken its instrument as their instructors. In a nutshell, nearly all characters of the novels are like actors; every new day they wear a new mask and act obediently based on their invisible teachers' orders.

\section{Ben as a stranger}

The other or stranger from Kristeva's perspective is a kind of challenge to the order of society and its main feature is its heterogeneity. She believes that those who can't embrace their strangers within will be unable to embrace the strangers outside. The novels of The Fifth Child and Ben in The World are full of others and strangers who have been portrayed by Lessing as outcasts.

The Fifth Child begins by the introduction of two strangers who are completely different from others; the foreigners are David and Harriet. Harriet is a virgin in her era, always ridiculed by her friends, while David seems peculiar from his peers' perspective; because, he is not so much in favor of making love with girls: "so what was it about these two that 
made them freaks and oddballs: it was their attitude to sex" (The Fifth Child 9); therefore, these two foreigners find each other familiar and get married. The strangers start challenging the normal by their way of living, such as their choice of home, their decision to have six children and other myriad cases. Little by little, the novels reveal other strangers such as Ben and females of the novels. Most of the novels' characters are females who are considered in their society as others, but the most prominent stranger is Ben, who as a retarded child is always despised by other people. The only subjects embracing him are females such as Rita, Teresa and old woman who from Kristeva's point of view are as crucial elements for the creation of respect to foreigners both inside and outside: "women today are called upon to share in the creation of a new society, where by choice rather than origin, through lucidity rather than fates, we should assure our children living space that within our tenacious national and identity forcing traditions will respect the strangeness of each person"(Kristeva 35).

As mentioned above, the best friends of Ben are females .The main reason for the interest is that all the females are respected in their society as second sex, behaved as foreigners; therefore, they try to embrace Ben in a hope to make a union with their within stranger. From Kristeva's perspective, all females of Ben's society are mature, for in her idea "the maturity of the second sex will be judged according to its ability to modify the nation in the face of foreigners, to orient foreigners confronting the nation towards as still unforeseeable conception of a polyvalent community"(Kristeva 35). In researcher's notion, all women of the novels are mature and intend to create a society in which strangers are respected like other people.

Ben is loved just by females and not males, but what is the reason for it? The main cause is that all males consider Ben just as a scapegoat; in other words, they desire to sacrifice Ben outside not to merge with their stranger inside. It is not really important for any of male characters if Ben is killed by police while carrying drugs. The society of males is like narcissistic image in which the child doesn't want to lose it and at the same time is worried for his social position. 


\section{Poor Banished Ben}

Ben in fact as a stranger or a banished subject tries his best to choose his banishment voluntarily. In Kristeva's notion, he, as a subject, makes himself completely separated from his paternal, meaningful and petrified society in which there is a permanence of meaning and goes somewhere else to get rid of his world. In other words, Ben goes in quest of somewhere in which paternal role is dead and this is the world of females. In the stage:

\footnotetext{
What the banished man needs most from a woman is someone to accompany him into the death's void, into the third person's void, he needs to gentle touch of a mute partner, renunciation of the body, waste, sublimation and in order to be faithful to his dead father to the end a double suicide. (Kristeva 152)
}

As discussed earlier, having rejected by his family, Ben becomes the same banished subject of Kristeva who is separated from paternal realm and is in an urgent need of a female partner, who can guide him toward death. The female in researcher's idea is no body but Teresa, who accompanies him to his last moment of life. Having banished from the paternal world, Ben experiences different kinds of females' love, but in order to remain faithful to his dead father he commits suicide, of course by the help of Teresa as his imaginary father.

\section{Ben the only stranger without any history}

Ben is the only stranger in the novels, who is without any ancestor and history, always yearning for it. As it is clear, from the first pages of the novel, Ben has become an outcast and alien; he has become completely distinct from his family to Teresa, Rita and Alfred, whom he thought capable of providing him with love. As a matter of fact, none of the characters can offer him the love, all of them just manipulate him consciously or unconsciously, so he as a stranger goes in quest of his history and people, but the search is of no avail. The only objects of love who promise him to show his people are Alfred and Teresa, but they show him just some rock figures engraved on mountain, and this is the 
moment in which Ben finds himself a real wanderer, devoid of any history, rejected and manipulated by all even those who pretend to be his friends. In the catastrophic state, Kristeva believes that the subject " finds nothing but death as the healing for his pain; no longer God or politics or others, but death alone becomes the source of an individuation that takes the form of radical severance" (77). As a matter of fact, no body helps Ben in finding his history and individuality; neither his mother nor men and women of his society could help him to pave the way toward his individuation. Thus no way remains for him but death; by death he probably can gain his self what he never became successful achieving during his life.

\section{Ben's choices as a stranger}

From Kristeva's point of view, the stranger has some options for living among other people as an individual: he can assimilate others, leave physically his home, reshape himself psychologically or reject the social codes which exist in his society. As a matter of fact, Ben is a real stranger in some social behaviors such as eating, clothing, laughing, etc but by degrees he finds that in order not to be rejected there remains no way but assimilation. In the state, he does his best to become similar to other people; in his family he starts imitating his siblings in every manner even in eating: "He scrambled energetically on to a chair, and set himself to be like them. He knew he must not talk with his mouth full... he carefully obeyed such imperatives, the energetic animal movement of his jaws confined behind close lips; waiting till his mouth was empty..." (Ben in The World 115). After leaving home, Ben tries to imitate other people's behavior and actions, but it is of no use. Accordingly, he finds himself completely different from others and cannot conceal the fact: "Ben is really trying very hard. He doesn't seem to fit in with the others it's hard to put one's finger on it" (ibid 120). Having accepted his differences, Ben finds no other way but redefining himself psychologically; in other words, he accepts that both in his thought and action he is a big difference: "I have never seen anyone like me, I don't have any people. I am not like my family at home; they are all different from me" (Ben in 
The World 126). He ,as an other, internalizes the fact that he is an other, but nobody respects his otherness. The main reason for the lack of understanding of those around Ben is that all of them lack the ideal love in which the subject can identify with others and simultaneously maintain his otherness .All the people are deprived of love, so there remains no way for Ben as a stranger but leaving physically; he leaves a place to another one and as a consequence leaves the world and commits suicide.

\section{Ben in exile}

Ben, as the protagonist of these two novels, does his best to be welcomed as an ordinary subject in his society which according to Kristeva's logic of exile : "all aims should waste away and self destruct in the ward even insane stride toward an elsewhere that is pushed back, unfulfilled, out of reach" (6 ).Based on Kristeva's concept of exile, Ben while finding nothing in common between himself and all those around him, goes in quest of people like himself; a place where his people live, a nowhere: “ the lost paradise is a mirror of the past that the foreigner will never be able to recover, the foreigner is a dreamer making love with absence" (ibid 10).Ben is the same Kristevan foreigner or better to say dreamer who is in search of his past. He even makes love with the rock figures engraved on the mountains: "Ben stood forward and stroke the outline of a female who seemed to be smiling at him, then he bent forward and nuzzled at her...letting out short cries that were greetings" (Ben in the World 175). To put it in Kristeva's word, it can be concluded that Ben as a stranger desires to embrace his people and his past, but while joining with his people, it becomes impossible for him to recover from his past, so he chooses death as the only remedy for the excruciating pain.

\section{Ben's paradise lost}

In Kristeva's notion, stranger belongs to nowhere and lives according to his relation to his paradise lost. Regarding the quality of the relation, Kristeva categorizes two groups of strangers: ironists and believers. Ironists are those foreigners who are completely hopeless and in favor of 
emptiness; while believers are meliorists, they are in search of improving their situation. In researcher's idea, Ben is a believer in every stages of his life; he tries very hard to make his situation better and to learn some vital social skills, he kills himself for being called a good boy. Ben does any act to improve his situation, but while finding other people completely reluctant to his attempts he craves for his paradise. The quest for the paradise lost is Ben's search for his imagined identity; since, his symbolic identity has been shattered to pieces by others as: "today's values crisis is because of a clash between our symbolic identity having strong demands and our imaginary identity rooted in original call (race, biology)" ( Kristeva 4).Regarding the quotation, Ben in the novels is the only individual who solves his self's clash, for his symbolic identity is annihilated in his symbolic society, so he goes in search of his original call which is his rocky people .

\section{Ben as a bomb of hatred}

Hatred is the prominent feeling of Ben, especially, in his relation with those who have rejected him such as his mother: "his eyes looked up at her in a glare of hate" (The Fifth Child 104). The same feeling exists when he has relationship with his siblings such as Paul and his father David. According to Kristeva: "hatred makes the foreigner real, authentic so to speak, solid/ simply existing" (Strangers to Ourselves 13). The strong hate always accompanies Ben; he is born with hatred, lives with it and dies by it. The hatred from Kristeva's notion, causes the subject to speak less and to be silent : "yet he spoke a little when he did say something it was never much more than yes or no" (The Fifth Child 146), of course, the main reason for the taciturnity is that people are not receptive to the stranger; all of them are deaf to his pains, so when he cannot utter his internal conflicts he recedes into his own world: "he was so sad, so lonely, but the darkness was his home, night was his place and people didn't look at you so dangerously at night" (Ben in The World 146). Ben has walled himself in darkness. It seems that a peaceful coexistence is between Ben and others, but there is a chasm between the foreigner and his deaf listeners; a gap which nothing can fill it, the 
stranger is always alone: "the knowledge of his aloneness was beating into him, you are alone, you are alone..." (ibid 77). Actually, the selfimprisonment causes the foreigner to have difficulty in confronting the others, exactly like Ben's problem; he is forced to imprison himself, to be silent and consequently to be replete with detestation because nobody understands him, nobody listens to him and ultimately nobody even values him as a subject.

\section{Conclusion}

The psychic cycle has many levels to be completed. From Kristeva's perspective, one of the stages is thetic break which is acquired by the help of imaginary father. Ben in the two novels of The Fifth Child and Ben in The World is a subject in process who tries to make his thetic break perfect by the help of his imaginary fathers, but the society which he steps into is a society of spectacle, full of individuals who are similar to automatons, doing submissively what their power orders them. In other words, in Ben's society every thing is under the gaze of the invisible power and for the strong control of ideology, some deeds become criterions for a successful person. One of those is financial prosperity which entraps subjects such as Johnston, David and Richard; in other words, in the society drives are not subjects' desires but those of society artificially produced, so in the catastrophic state, self- alienation of individuals and creation of stranger occurs. .Ben is the most obvious example of a stranger in the novels, who because of his peculiar physical and mental condition is excluded by all characters of the novels except women.

Kristeva is known to be a cosmopolitan, and as a cosmopolitan she is completely against any exclusion and is so much in favor of inclusion and embrace of the strangers. She claims that a flexible nation can create the ideal situation, and it is through the establishment of the utopian nation that her dreams can come true:

Indeed I am convinced that in the long run, only through investigation of our remarkable relationship with the other and strangers within ourselves can lead people to give haunting for the scapegoat outside their group, a search that allows 
them to withdraw into their own "sanctum" thus purified, is not the worship of one's very own of which the national is the common denominator that we imagine we have as our own along with other own and proper people like us? (Kristeva, Strangers to ourselves 51)

As a conclusion of what explained in previous pages, the researcher would like to finish the part by the following statement that according to Kristeva's notion should be engraved on the wall of all schools, and become a touchstone for all cosmopolitans:

If I know something useful to myself and detrimental to my family, I would reject it from my mind. If I know something useful to my family, but not to my homeland, I would try to forget it. If I know something useful to my homeland and detrimental o Europe, or else useful to Europe and detrimental to mankind I would consider it a crime. (ibid 63)

It is hopeful and exhilarating to envisage the future world as an integrated nation in which all others such as Ben and females find themselves capable of being respected and welcomed as ordinary individuals. 


\section{References}

---.Black Sun.Trans.Leon S.Roudiez . New York: Colombia University Press, 1980

---.Hatred and Forgiveness.Trans.Jeanine Herman. New York: Colombia University

Press, 2010

---.Nations Without Nationalism. Trans.Leon S.Roudiez. New York:

Colombia University

Press, 1993.

---, Power of Horrors.Trans.Leon S.Roudiez.New York: Colombia University Press,1982:2-

120.

---. "Revolution in Poetic Language." The Kristeva Reader.ed.Moi.New York:Colombia

University Press, 1986.

---.Strangers to Ourselves. Trans.Leon S.Roudiez.New York: Colombia University Press, 1991.

Letche, John, and Maria Margaroni.Julia Kristeva,Live theory .New York:Continuum,2004.

McAfee, Noelle. Julia Kristeva. New York and London: Routledge ,2004.

Oliver, Kelly. "The Crises of Meaning." The Kristeva Critical Reader.ed.Letche and

Zournazi.Edinburg:Edinburg University Press Ltd,2003:36-92.

Rowe, Margaret. "Dreaming Fathers, Practical Mothers and Lessing's Fiction." Science Fiction Studies 22,2 (November 2011 ):291-293 Yi-ping, Ong . "Existentialism, Realism and Novel. " Diss. University of Harvard.1999. 